\author{
G.G. Meyramov ${ }^{1 *}$, K.-D. Kohnert ${ }^{2}$, V.I. Korchin ${ }^{3}$, \\ G.T. Tusupbekova ${ }^{4}$, A.S. Shaybek ${ }^{1}$, A.G. Abdraimova-Meyramova ${ }^{5}$ \\ ${ }^{I}$ Karagandy University of the name of academician E.A. Buketov, Karaganda, Kazakhstan; \\ ${ }^{2}$ Institute of Diabetes «Gerhardt Katch», Karlsburg, Germany; \\ ${ }^{3}$ State Medical Academy, Khanty-Mansyuisk, Russia; \\ ${ }^{4}$ Pavlodar Innovation University, Kazakhstan; \\ ${ }^{5}$ Karaganda Medical University, Kazakhstan \\ *Corresponding author: meyramow@mail.ru
}

\title{
Histophotometric complex for quantitative estimation of Insulin and Zinc Content in Pancreatic B-cells
}

\begin{abstract}
It is presented a developed and constructed histophotometric complex for quantitative evaluation in relative units of content of deposited insulin and zinc in insulin-producing B-cells of histologic preparations of pancreas. The method previously used in similar studies was based on a visual assessment of the results of coloring the preparations, or a more accurate quantitative one under the conditions of using universal complexes, including a microscope with built-in measuring devices (photometers), the disadvantage of which is, as a rule, a very high cost limiting the possibility of their use. In addition, such complexes, in connection with their universality, are not suitable for studies related to the study of the functional state of pancreatic B cells using highly specific histochemical methods for detecting insulin. The authors aimed to develop and create a studyoriented histophotometric complex of zinc and insulin in B cells, created using inexpensive components, which would help make quantitative analysis significantly more accessible to researchers working in the field of experimental diabetology.
\end{abstract}

Keywords: B-cells, insulin, zinc, histophotometric complex.

\section{Introduction}

Histochemical methods for estimation of functional activity of pancreatic B-cells possess at least a few advantages in compared with biochemical methods for assessment of the ability of pancreatic B-cells to synthesize insulin: 1) the researcher assesses the insulin content in the B-cells by direct observation of cells using of micro- scopy, while biochemical methods give a digital assessment, not allowing to observe cells visually; 2) histochemical and histological methods allow, in addition, to analyze the state of the histostructure of B-cells and of pancreatic tissue, which improve the value of the results.

The disadvantage of histochemical methods for assessing the results of insulin measuring is the approximate amount of hormone in B-cells, based on a visual investigation of the color density or intensity of fluorescence of hormone. Factory made microscopes with photometric devices with built-in photometric devices have two significant drawbacks: 1) they do not allow to diaphragm of pancreatic islet's central part, contains only B-cells in the photometry field, thereby allowing photometry of cells of the exocrine pancreas, which have nothing to do with insulin synthesis; 2) such optical systems are almost always universal, that is, very expensive, because they include a number of other functions that do not have any special need for investigators.

\section{Experimental}

Authors are proposed a developed and manufactured histophotometric complex for selective photometry of B-cells after staining by specific for insulin and zinc methods adopted for light and ultraviolet microscopy as aldehyde-fucshin staining, diethylpseudoisocyanine methods, staining by Dithizon and immunohistochemical method $[1-6,8,9]$. In the supplement to the complex, repeatedly tested and refined cal- culation methods have been developed that allow estimate the insulin and zinc content in B-cells.

The system includes the following components: 1) microscope; 2) a light source (a lamp of the usual part of the spectrum and an ultraviolet lamp with opaq-porthole); 3) microphotosystem MFN-2 (LOMO) with a built-in lobe diaphragm that allows us to diaphragm the central part of pancreatic islet containing B-cells, that is why is excluded the possibility of photometry of A-cells and, especially, cells of exocrine tissue. The diaphragm was mounted as close as possible to the photomultiplier tube, above ocular for to prevent 
light flux scattering. The design of the optical part of the system is completed by photomultiplier tube. The complex includes a power component with five measuring ranges for the photocurrent value and a microammeter (Fig. 1, 2), the readings of which (in microampers $(\mu \mathrm{A})$ are the initial data for calculation of insulin and zinc content in B-cells as relatives units (r.u.). The used filters: UVS-1 located between lamp and microscope; and yellow filter locking light filter fixed on ocular of microscope. Used optic: objective $\times 40$; oculars: $\times 3$ or $\times 4$. Note: If necessary, the photomultiplier tube is easily replaced by a camera for microphotography of the studied B-cells.

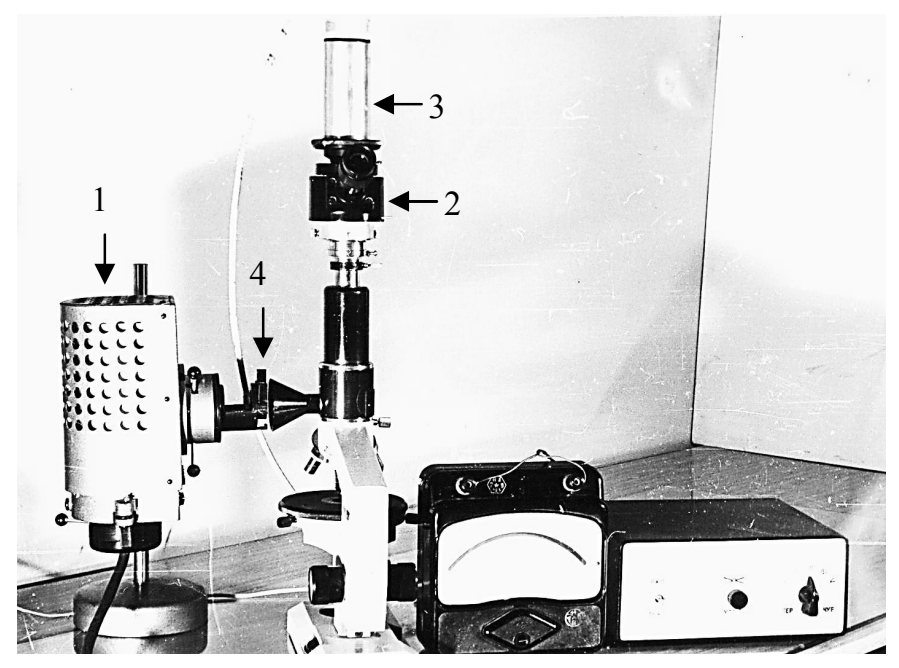

1 - UV-lamp; 2 - a petal diaphragm built into microscope; 3 - photomultiplier ФЭУ-31; 4 - opaq-porthole; to the right of the microscope: microammeter and electrical unit

Figure 1. Histofluorimetric complex on the base of microscope «Biolam-R»

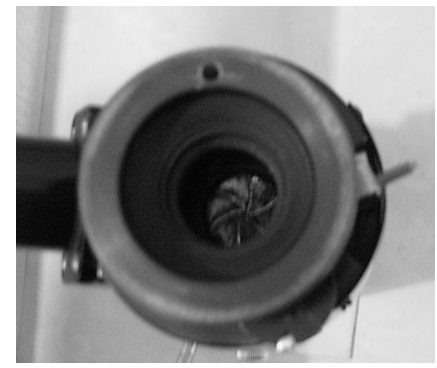

a)

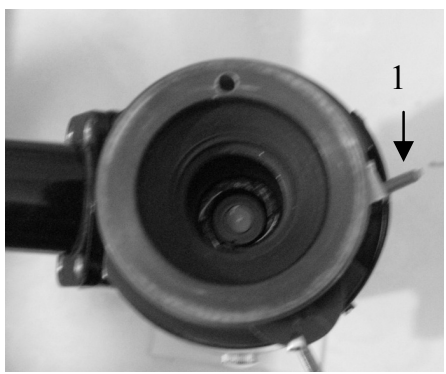

b)

1 - handle for to open diaphragm

Figure 2. Diaphragm is open minimally $(a)$; diaphragm is open $(b)$

\section{Methods for investigation of insulin and zinc content in pancreatic B-cells}

In frozen sections or sections of fixed pancreas tissue stained for insulin and zinc using highly specific methods [1-10], the fluorescence intensity of B-cells is measured in microamperes $(\mu \mathrm{A})$ of a islet's central part contains B-cells. The required number of studied islets is 20-25. For the first B-cells of control intact animals contains a normal amount of insulin and zinc are examined; calculation the arithmetic mean of $\mathrm{mA}$ $(\mathrm{M} \pm \mathrm{m})$ of the fluorescence intensity; similarly measure the intensity of fluorescence of B-cells of experimental animals, for example, with diabetes, which is always much lower than normal.

The direct proportional dependence was used in the calculation: the more intense fluorescence result the higher light flux going to the photometer and the higher the content of insulin and zinc in B-cells.

For histochemical methods adopted for light optical microscopy (aldehyde-fuchsin, immunohistochemical, Victoria-4 method with dimethylnaphthylmethane staining reagent, color index 42563) the inverse dependence is used to calculate the parameter $\mathrm{K}$, namely: the higher insulin content $\rightarrow$ result more intensive density of staining of B-cells $\rightarrow$ that result a lower intensity of the light flux goes to the photometer and the lower the photocurrent value expressed in $\mu \mathrm{A}$. 

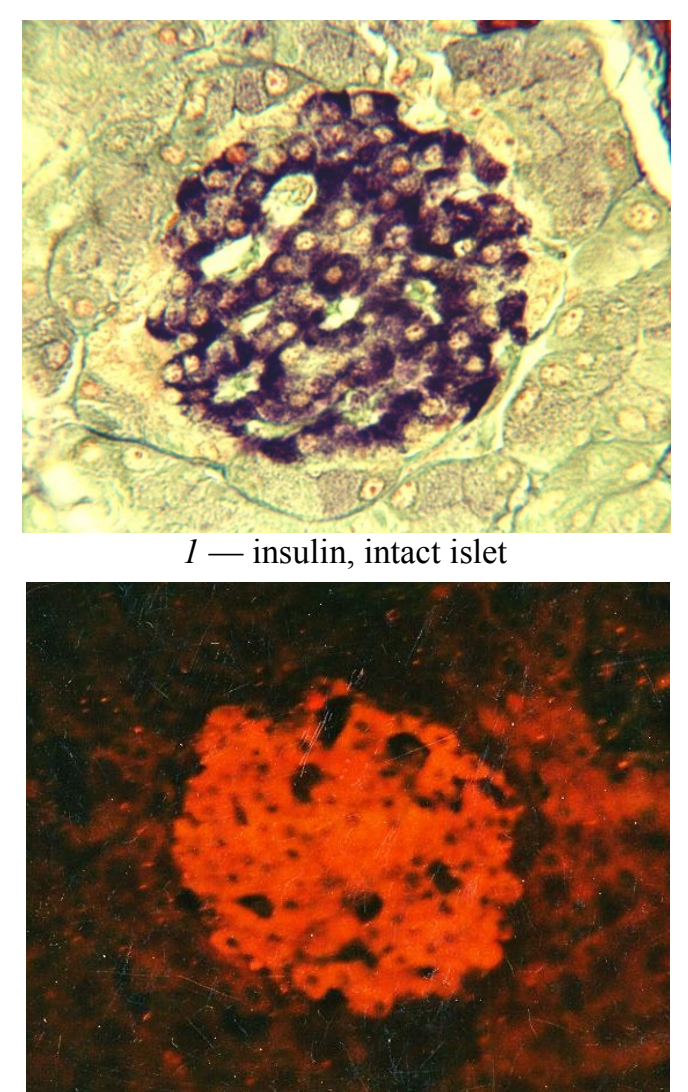

3 - insulin, intact islet

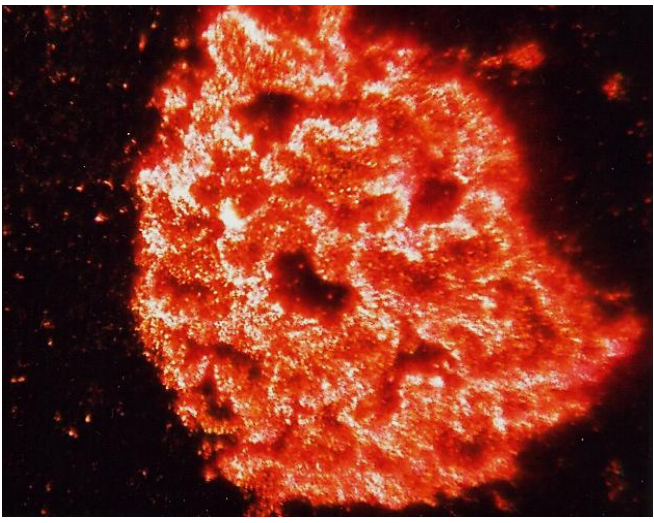

5 - zinc; intact islet

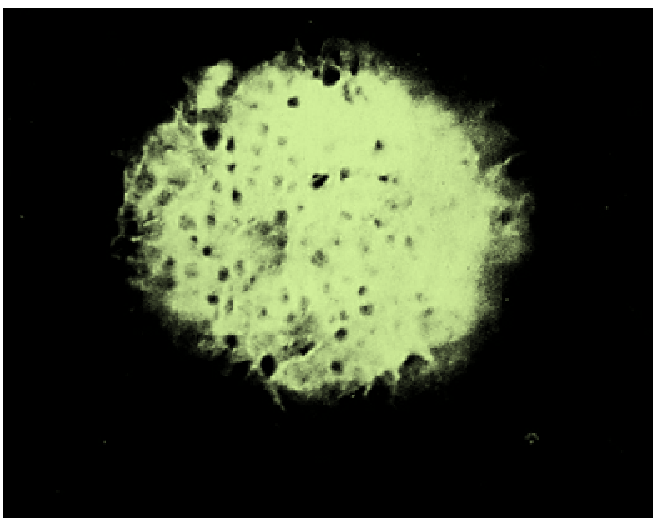

7 - zinc; intact islet

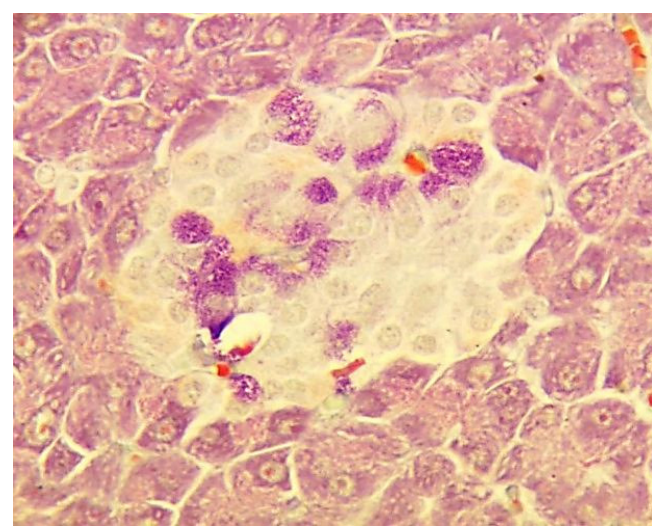

2 - insulin; diabetes...

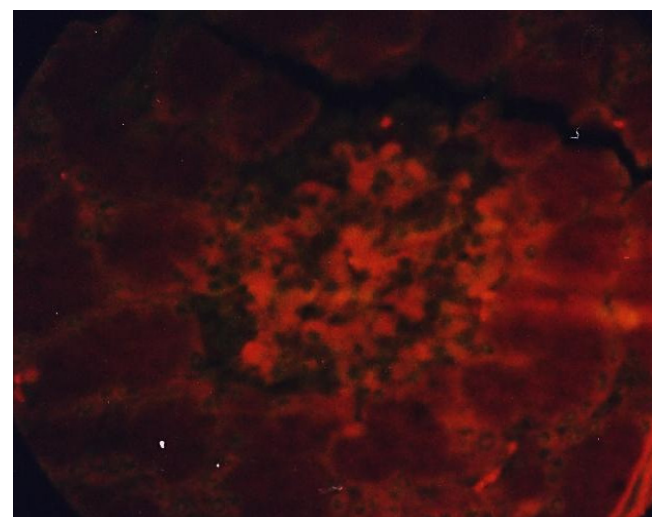

4 - insulin; diabetes...

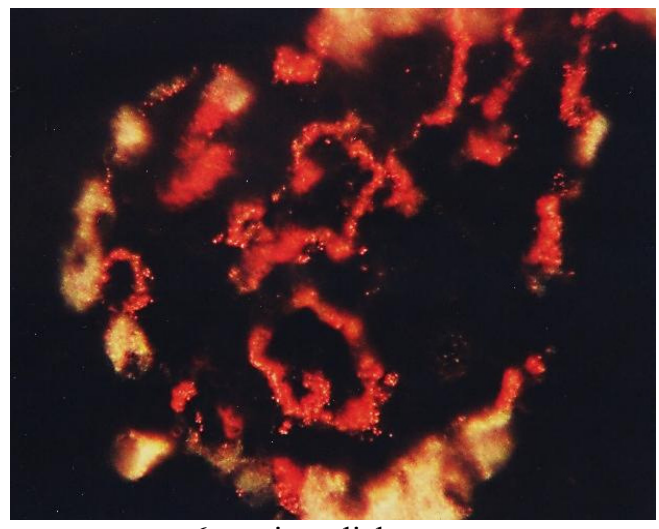

6 - zinc; diabetes...

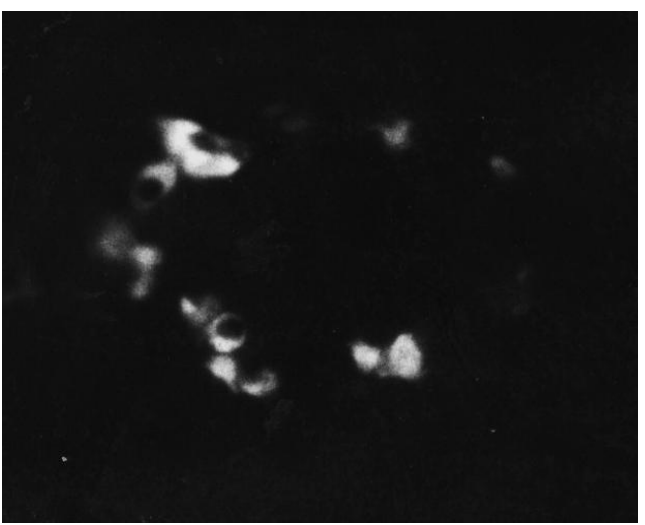

8 - insulin; diabetes...

1, 3, 5, 7 - intact islets; 2, 4, 6, 8- destruction of islets; staining by aldehyde-fucshin $(1,2)$; diethylpseudoisocyanine $(3,4)$, dithizon $(5,6)$; TSQ $(7,8)$

Figure 3. Insulin and zinc content in pancreatic B-cells of intact and damaged islets in diabetes 
The results presented in Table 1 and in Figure 3 showed that most marked differences of the quantitative assessment of insulin and zinc content in intact and damaged B-cells were obtained using high specific luminescent staining methods of pancreatic islets, as well as using of Dithizone method. Staining by using of aldehyde-fuchsin method and the Victoria 4 method, accompanied by additional staining of other cellular structures result increase of the total color density in addition to colored of B-cells for insulin, which result increasing of the value of density of color, which characterizes the level of insulin in the B-cells. Fluorescent histochemical methods staining of insulin or zinc only without staining of other cellular structures, due to which the assessment of hor- mone and zinc content in B-cells are that is why more accurately.

$\mathrm{Tab} l \mathrm{e} 1$

Quantitation by photometry of Insulin and Zinc content in control and diabetic pancreatic B-cells

\begin{tabular}{|c|l|c|c|}
\hline No. & \multicolumn{1}{|c|}{ Staining technology } & Intact & Diabetes \\
\hline \multirow{2}{*}{1} & Aldehyde-fucshin (insulin) & $\begin{array}{c}1.89 \pm 0.08 \\
n=18\end{array}$ & $\begin{array}{c}0.42 \pm 0.04^{*} \\
n=23\end{array}$ \\
\hline \multirow{2}{*}{2} & Diethylpseudoisocyanine (insulin) & $\begin{array}{c}1.96 \pm 0.06 \\
n=20\end{array}$ & $\begin{array}{c}0.23 \pm 0.01^{* *} \\
n=25\end{array}$ \\
\hline \multirow{2}{*}{3} & Dimethylnaphtylmetan (Victoria 4R) (insulin) & $\begin{array}{c}1.94 \pm 0.08 \\
n=24\end{array}$ & $\begin{array}{c}0.56 \pm 0.06^{*} \\
n=19\end{array}$ \\
& & $2.04 \pm 0.05$ \\
\multirow{2}{*}{4} & Dithizon (zinc) & $n=31$ & $\begin{array}{c}0.20 \pm 0.01^{* *} \\
n=28\end{array}$ \\
\hline \multirow{2}{*}{5} & TSQ (zinc) & $2.00 \pm 0.03$ & $n=34$ \\
\end{tabular}

Note. Values are represented as milliampere $(\mathrm{mA} \pm \mathrm{SD}) ;{ }^{*} \mathrm{p} \leq 0.005 ;{ }^{*} \mathrm{p} \leq 0.001$ vs. controls.

\section{Conclusions}

1. Histofoto- and fluorimetric complex allows performing two main functions: 1) quantitative measuring of the content of deposited insulin and zinc in B cells; 2) visual observation and microphotography of Bcells of pancreatic islets; thus, the final protocol of the investigation includes: 1) digital data on the content of insulin and zinc in B-cells; 2) data describing a visual investigation of state of histostructure of tissue; 3) microphotographs of pancreatic islets

2. The complex consists of inexpensive and affordable components, which makes it many times cheaper than universal prefabricated complexes

\section{References}

1 Meyramov G.G. The High Specific Method for Revealing of Zinc in Pancreatic B-cells / G.G. Meyramov, G.T. Tusupbekova, R.G. Meyramova // Diabetes. — 1991. - Vol. 40, No. 1. — P. 65.

2 Красавин И.А. Гистохимические реакции на цинк в островках Лангерганса и диабетогенная активность используемых для этой цели реактивов / И.А. Красавин, 3.Е. Бавельский, Я.А. Лазарис, В.М. Дзиомко // Проблемы эндокринологии. - 1969. - T. 21, № 3. - С. 102-105.

3 Meyramov G.G. The Histofunctional Method appreciating of Functional State of Isolated Pancreatic B-cells in the tissue culture / G.G. Meyramov, G.T. Tusupbekova, H. Niedderer // Diabetes Research and Clinical Practice. — 1988. — Vol. 5, No. 11. — P. 226-227.

4 Kvistberg D. Staining of insulin with aldehyde fucshin / D. Kvistberg, G. Lester, A. Lasarov // J. Cytochem. — 1966. Vol. 14. - P. 609-611.

5 Coalson R.E. Pseudoisocyanin staining of insulin and specifity of emperical islet cell stain / R.E. Coalson // Stain Technol. 1966. — № 2. - P. 121-129.

6 Kikui Y. Differential staining method for A- and B-cells in the pancreatic islets of Langerhans / Y. Kikui, H. Seguchi, H. Mizoguti // Acta Histochem. Cytochem. - 1977. — Vol. 10, No. 1. — P. 10-13.

7 Мейрамов Г.Г. Предварительный патент РК № 18352 от 08.01.2007. «Метод оценки содержания инсулина в панкреатических островках в эксперименте» / Г.Г. Мейрамов, А.А. Кикимбаева, А.Г. Мейрамова.

8 Wohlrab F. On the specify of the Insulin staining by Victoria Blue 4R / F. Wohlrab, H. Dorsche, I. Krautschick, S. Schmidt // Histochem. Journal. — 1985. — Vol. 17. - P. 515-518.

9 Meyramov G.G. The High specific fluorescent histochemical method for staining of insulin in B-cells of isolated pancreatic islets / G.G. Meyramov, A.A. Kikimbaeva, A.G. Meyramova // Acta Diabetologica. - 2005. - Vol. 42, No. 1. - P. 66.

10 Meyramov G.G. Victoria 4R Method Staining of Insulin in B-cells of Isolated Pancreatic Islets / G.G. Meyramov, A.G. Meyramova, A.A. Kikimbaeva // Acta diabetologica. — 2003. — Vol. 40, № 4. — P. 208. 
Г.Г. Мейрамов, К.-Д. Конерт, В.И. Корчин, Г.Т. Тусупбекова, А.Ж. Шайбек, А.Г. Абдраимова-Мейрамова

\title{
Ұйқы безінің В-жасушаларындағы инсулин құрамын сандық бағалауға арналған гистофотометриялық кешен
}

\begin{abstract}
Ұйқы безінің гистологиялық препараттарының инсулин шығаратын В-жасушаларындағы сақталған инсулин мен мырыштың құрамын салыстырмалы бірліктерде сандық бағалау үшін әзірленген және құрастырылған гистофотометриялық кешен ұсынылған. Бұрын мұндай зерттеулер кезінде пайдаланылатын әдіс препараттардың бояу нәтижелерін визуалды бағалауға немесе әмбебап кешендерді қолдану жағдайында дәлірек сандық бағалауға негізделген, оның ішінде кіріктірілген өлшеу құрылғылары (фотометрлері) бар микроскоп кіретін, оның кемшілігі, бағасы жоғары болғандықтан, оларды пайдалану мүмкіндігі шектеулі болатын. Бұдан басқа, мұндай кешендер олардың әмбебаптығына байланысты инсулинді анықтаудың жоғары мамандандырылған гистохимиялық әдістерін пайдалана отырып, панкреатикалық В-жасушалардың функционалдық жайкүйін зерттеумен байланысты зерттеулер үшін аз жарамды. Авторлар қымбат емес компоненттерді пайдалана отырып құралған гистофотометриялық кешенді әзірлеу және жасау мақсатын қойды, бұл тәжірибелік диабетология саласында жұмыс істейтін зерттеушілерге сандық талдауды барынша қол жетімді етуге мүмкіндік береді.
\end{abstract}

Кілт сөздер: В-жасушалар, инсулин, мырыш, гистофотометриялық кешен.

\section{Г.Г. Мейрамов, К.-Д. Конерт, В.И. Корчин,} Г.Т. Тусупбекова, А.Ж. Шайбек, А.Г. Абдраимова-Мейрамова

\section{Гистофотометрический комплекс для количественной оценки содержания инсулина в В-клетках поджелудочной железы}

\begin{abstract}
В статье предложен разработанный и сконструированный гистофотометрический комплекс для количественной оценки в относительных единицах содержания депонированного инсулина и цинка в инсулинпродуцирующих В-клетках гистологических препаратов поджелудочной железы. Ранее используемый при подобного рода исследованиях способ базировался на визуальной оценке результатов окраски препаратов, либо более точный количественный в условиях применения универсальных комплексов, включающих микроскоп со встроенными измерительными устройствами (фотометрами), недостатком которых являлись, как правило, весьма высокая стоимость, ограничивающая возможность их использования. Кроме того, такие комплексы в связи с их универсальностью малопригодны для исследований, связанных с изучением функционального состояния именно панкреатических В-клеток с использованием высокоспецифичных гистохимических методов выявления инсулина. Авторы пытались разработать и создать ориентированный специально для исследований содержания цинка и инсулина в В-клетках гистофотометрический комплекс, созданный с применением недорогих компонентов, что помогло бы сделать количественный анализ значительно более доступным для исследователей, работающих в области экспериментальной диабетологии.
\end{abstract}

Ключевые слова: В-клетки, инсулин, цинк, гистофотометрический комплекс.

\section{References}

1 Meyramov, G.G., Tusupbekova, G.T., \& Meyramova, R.G. (1991). The High Specific Method for Revealing of Zinc in Pancreatic B-cells. Diabetes, 40(1), 61-65.

2 Krasavin, I.A., Bavelsky, S.E., Lazaris, Y.A., \& Dziomko, V.M. (1969). Histokhimicheskie reaktsii na tsink v ostrovkakh Lanherhansa i diabetohennaia aktivnost ispolzuemykh dlia etoi tseli reaktivov [Histochemical reaction for zinc in islets of Langerhans and diabetogenic activity of used reagents]. Problemy endokrinolohii - Problems of endocrinology, 21, 3, 102-105 [in Russian].

3 Meyramov, G.G., Tusupbekova, G.T., \& Niedderer, H. (1988). The Histofunctional Method appreciating of Functional State of Isolated Pancreatic B-cells in the tissue culture. Diabetes Research and Clinical Practice, 5(11), $226-227$.

4 Kvistberg, D., Lester, G., \& Lasarov, A. (1966). Staining of insulin with aldehyde fucshin. J. Cytochem., 14, 609-611.

5 Coalson, R.E. (1966). Pseudoisocyanin staining of insulin and specifity of emperical islet cell stain. Stain Technol., 2; 121129.

6 Kikui, Y., Seguchi, H. \& Mizoguti, H. (1977). Differential staining method for A- and B-cells in the pancreatic islets of Langerhans. Acta Histochem. Cytochem., 10(1), 10-13. 
7 Meyramov, G.G., Kikimbaeva, A.A. \& Meyramova, A.G. (2007). Predvaritelnyi patent RK № 18352 ot 08.01.2007. «Metod otsenki soderzhaniia insulina $v$ pankreaticheskikh ostrovkakh v eksperimente» [Preliminary patent of RK No. 18352 dated 08.01.2007. «Method for estimating insulin content in pancreatic islets in an experiment»] [in Russian].

8 Wohlrab, F., Dorsche, H., Krautschick, I. \& Schmidt. S. (1985). On the specify of the Insulin staining by Victoria Blue 4R. Histochem. Journal, 17, 515-518.

9 Meyramov, G.G., Kikimbaeva, A.A. \& Meyramova, A.G. (2005). The High specific fluorescent histochemical method for staining of insulin in B-cells of isolated pancreatic islets. Acta Diabetologica, 42(1), 66.

10 Meyramov, G.G., Meyramova, A.G. \& Kikimbaeva, A.A. (2003). Victoria 4R Method Staining of Insulin in B-cells of Isolated Pancreatic Islets. Acta diabetologica, 40(4), 208. 